\title{
The New Agricultural History The American Prairie Agriculture in a Wider Context
}

By

Erik Helmer Pedersen

Associate Professor, University of Copenhagen

The heading of my article seems to indicate that a new broad design or a leading hypothesis has been put forward in American agricultural history, a new way of doing historical research and writing.

I am sure, however, that any of my American colleagues will object to such an idea on my part. They will surely maintain that you can only speak about an evolutionary process. American scholars in that field do not need any conceptual framework, they will say. ... Of course you can find various attempts at writing broad synthesises such as a recent new book by John T. Schlebecker ${ }^{1}$ and William N. Parker's comparison of technological change in Europe's industrial revolution and in American agriculture: artisan industry, the classic Industrial Revolution, and the new impetus given by modern science to productivity increases. ${ }^{2}$ The Agricultural History Society in America has tried to remedy that calamity by producing a whole range of symposium volumes on major themes and periods of American agricultural history. ${ }^{3}$

But all these unifying efforts have, in my opinion at least, not produced the needed coherence in the historiographic development during the last fifty years or so. Instead of this I will try to arrange the most interesting achievements in that respect in a development scheme. To that end I will start by recalling the very origins of American historical writings on the subject.

In 1893 Frederic Jackson Turner presented his so-called "frontierthesis" to an audience in Chicago. " "The existence of an area of free land, its continuous recession, and the advance of American 
settlement westwards explains American development."5 An Americanization took place, said Turner, when the pioneers passed the borderline between the European styled civilization and the wilderness of the American west.

Ever since, this grand thesis has functioned as the most influential set of ideas yet presented in American historiography, says Lee Benson. ${ }^{6}$ I am certainly not going to enlarge on the Turner Thesis and its general significance here. I want rather to exemplify the importance of the thesis by stressing the fact that here we have the very foundation of most of the historical writings so far on the establishment of Northwest and Midwest American agriculture. Here we see the impact of the unique physical and spiritual framework which the American scene presents.

Many years later another American historian, James C. Malin, stated that Turner's thesis was a closed-space, geographical concept of American history. It was, in his opinion, primarily an agricultural interpretation. Malin felt that it was too simple, not allowing for the fact that there were still opportunities created by the fluidity of society, based on industrial urbanism.'

Another interpretation of Turner's thesis must also be discussed if we are to value the impact of it. In 1896 Turner claimed that the rise of the farmers' movement, the so-called "populism", was due to the fact that there was no more free land available. America no longer possessed the material basis for continued social and cultural rebirth. ${ }^{8}$ One may argue, therefore, that the Turner thesis is also the basic design of the history of the American populism.

The central idea of the Turner thesis, that the struggle with the open land made all pioneers echt Americans, has of course a great following among American historians of the Wild West. As late as in 1837 Everett Dick issued a very influential book on the social life at the frontier. ${ }^{9}$ Here he soundly declared that the frontier had been the "most important single factor of the 'American way of life' from Jamestown to the early twentieth century."

Rut a reaction had already set in. In 1937, Paul W. Gates published his first book, ${ }^{10}$ in which he, maybe a little hesitatingly, began using real source materials in order to tell it like it was, not how it should have been. In a continuing stream of thoughtprovoking articles and books Gates has tried to expose all the corruptive elements of the American land policies on the 19th century. To Gates the scoundrel was without doubt the greedy land speculator and great landowner, while the hero was the Jeffersonian 
family farmer, who cultivated his land without lapses into economic speculation. For the first time in American history the tenant and the land worker received as much attentions of Turner's independent, democratic, free-holding, small farmer.

I have already mentioned the name of James C. Malin. He did not reject the Turner thesis altogether, but in several books and articles he pointed out that when the farmer moved westwards he had to master the local climate and soil, to change his methods of farming, if he was to prosper, to survive.11 Malin advocated, in fact, an ecological interpretation of American agricultural history. ${ }^{\mathbf{1 2}}$

Before we begin to discuss the next important step in the formation of the new agricultural history we have to go a little backwards to the populists and their historians. They are perhaps more widely known, since their problems have been drawn into the process of American self-understanding. In the Turner period two important books were published, in which their authors showed a sympathetic attitude towards the populists. ${ }^{13}$ After the Second World War came a wave of critical contributions, including Richard Hofstadter's well-known book on the subject. ${ }^{14}$

Next we had a new generation of anti-revisionists, ${ }^{15}$ who, on the contrary, said that populism was part of the American heritage. "Populism is our conscience and we cannot face it", they solemnly declared. Fred A. Shannon, who has written a widely acclaimed book on those movements, ${ }^{16}$ is rather inclined to show an understanding attitude towards most of their complaints. He openly states that agriculture does not lead to prosperity and that the agricultural ladder only leads downwards, not upwards, at least after 1880. Here he alludes to part of the Turner thesis, which says that the frontier functioned as a safety-valve for the American community as a whole. It eased the employment situation among American urban workers in the east, as, when unemployed, they might just go to the frontier to get a new job, a new start in life. Shannon had in fact, in an earlier article, opposed the idea. The west actually attracted millions of Europeans, while the American eastern workers, on the other hand, remained in their cities. ${ }^{17}$

I now presume that we have sufficient background for looking at the next phase in the historiographical development. The leading figure here is undoubtedly Allan G. Bogue, together with his wife, Margaret Beattie Bogue..$^{18}$ In his very first book ${ }^{19}$ he acknowledged his debt to Paul W. Gates by dedicating it to him. In his foreword he declared: "As yet our understanding of the role of land credit 
along the middle border has been perverted by the hysteria of the Populist era'.'. He first makes a close investigation of the business records of two land mortgage companies, confronted with the actual money-lending behaviour of the farmers in two townships in Kansas and Nebraska. The farmers in question were not, in fact, in the pockets of greedy speculators and capitalists. Admittedly they had to pay some very high interest rates, especially in the start of the settlement period, but in the beginning of this century the rates were more than halved. The farmers surely needed capital to modernize and equip their farms and therefore they had to pay the interest rates demanded.

Bogue's next book - and a very important work too - is dedicated to James C. Malin and Fred A. Shannon. ${ }^{20}$ Here he declares that he will "consider the whole range of problems confronting the operator of a farm business on the prairies." Consequently Professor Bogue follows the settlement and the development of farming techniques step by step, striving to re-create the pioneer farm in all respects from the primitive sod-house to the establishment of a farm with stock, implements and machines. To this end he uses an immense amount of primary source data, such as the original lists from the agricultural and demographic censuses, land office tract books, mortgage and deed registers, and county official records of all types - just as we should have done here in Denmark!

In his very thoughtful and carefully worded conclusions he places the farmer in the role of an economic man, who reacts to the problems in a very direct and rational manner. It is, therefore, fully understandable that not a few farmers chose to go further westwards. Some also took up a position as a tenant. Allan Bogue has in fact been able to calculate how many farmers were tenants before 1880, as the earlier censuses did not register the amount of tenancy.

Bogue is also able to confirm his conclusions from his first book, that the operations of the land speculator and the money lender were in fact a means of sending capital to regions that were desperately in need of it. Often the farmers themselves were pocket speculators. Also, it frequently happened that the resident farmers taxed the non-resident landowners very heavily indeed.

Allan Bogue's research and writing has of course created something of a new paradigm in American agricultural history. Without openly distancing himself from the Turner thesis, he has nevertheless been able to characterize the typical pioneer farmer in the mid- 
west, who reacts rationally to the natural facts of the surroundings and to the economic conditions of his day. The farmers worked in the framework of a free, capitalist society and consequently they paid the price demanded for the money and the services they were calling for.

A small army of Bogueians have followed in the master's footsteps and have certainly produced some results of far-ranging significance. Robert P. Swierenga has confirmed that the nonresident landowners actually suffered from discriminatory taxation of varying degrees. ${ }^{21}$ In a later book, explicitly termed as an "empirical historical study", he has gone through the source materials relating to the system of tax buying in frontier Iowa, the so-called tax auctions, and finds that the problem can be viewed as a means to procure regular state government revenue together with money for private development. ${ }^{22}$

Other historians have focused on tenant farming on the prairie, ${ }^{23}$ the role of the great landowner, exemplified in the career of an Irish capitalist of the 19th century, William Scully, ${ }^{24}$ and the actual agricultural terms of trade.

In several of these studies the authors have used rather advanced statistical and econometric procedures, an offshoot of the New Economic History multidata engineering process. Allan Bogue and Richard E. Easterlin have, for example, discussed the topic of Population Change and Farm Settlement. Bogue is duly impressed by the new techniques Easterlin and others use, but rather less by the actual results they generate.

In chapter ten of his Corn Belt-book Bogue also discusses the role of the innovator. "Some are innovators", his heading says. Even if he ends this chapter with some cautiously worded remarks on the possibility of studying innovations and innovators in a sociological context, a good many articles have been produced during the 1970 's on that topic. I shall restrict myself to the mention of only one article. ${ }^{25}$ Here the author asserts that there is a close correlation between the diffusion of techniques and technology and the general attitude climate in the neighbourhood in question.

Somewhat more interesting are the many articles on historical geography which have been published during the last few years. The Canadian geographer D. Aidan McQuellan has, for example, written two articles on three groups of immigrant farmers in central Kansas, the Swedish, the French-Canadians, and the RussianGerman Mennonites. ${ }^{26}$ In the paper from 1979, he concludes that 
the pioneer phase of settlement does not appear to have been much more mobile than the mature phase of settlement some thirty or forty years later. Here he is in accord with earlier historians such as Milred Throne, ${ }^{27}$ Merle Curti, ${ }^{28}$ and Allan Bogue, ${ }^{29}$ who found that the Europeans' supposed devotion to the soil is not quite as stubborn as has earlier been thought. Two years ago, the historian Jon Gjerde, from the University of Minnesota, showed that the ethnic community church functioned as a social institution of the very first order, as it assisted people in adapting themselves to the new situation in the immigration area. Consequently, migration and mobility were less frequent among people whose ties to the church community were strong. ${ }^{30}$

To me at least, it is obvious that we are on the verge of changing paradigm again when we speak about American agricultural history. Now, ethnic peculiarities and distinctions are allowed to be viewed as extremely significant factors in the making of American farming on the prairies. The accent is now placed not so much on merely economic motives and behaviours, as on the attractions of a community life in the local parish. People emigrated, tied up with family and kinship bonds, they very often settled down in the same locality in America, and they strived to transplant the practices and customs they had duly mastered in the old country.

To some extent, second generation members of an ethnic group mixed more with the Old Americans and other neighbouring groups. When we use their own letters and diaries as primary sources, we are able to make a very close study of how they assimilated themselves as economic, social, and political persons. The ring is closed. In the last decades of the 19th century they wrote all the so-called "mug"-books, in which they recorded the careers of the successful farmers. Now we are back on the individual plane, but we look just as much - and perhaps more - for details which might illuminate the lives and the deeds of all the members of a local community on the prairie.

\section{Some Afterthoughts}

I would like to conclude my article by enlarging its scope somewhat. So far I have tried to show that, seen in a historiographical context, American historians have, more or less, given up the idea of interpreting the American agricultural past as a very unique, not to say American, development. Instead, like the majority of their 
European colleagues, they try to understand the process by which subsistence agriculture was transformed into commercial agriculture, in terms of broad economic change in the world as a whole. Consequently, it is possible to draw a parallel between agricultural and industrial change. In both cases it results in a growing pressure on existing resources. It leads directly into sharp competition among the various branches of the trade. The farmers often find themselves in a completely new role as employers. The economic policies of the government in question will gradually pay more attention to the industrial sector than to the agricultural one, as the greater part of the population now earns its living in the towns. Now the farmers loudly demand to be supported by their government. If they do have a dominating position in a peculiar sector of agricultural exports, they will normally try to oppose all too devastating tariff policies. On the other hand, they do not themselves refrain from reserving the national market for goods which might otherwise be bought more cheaply in a foreign country.

When the Danish farmers learned that the grain prices in Britain fell very markedly during the 1860's and 1870's, owing to the fact that American grain in larger and larger quantities was dumped on the market, they slowly began to find another way of producing agricultural commodities. Instead of producing grain for export they simply fed it to their milking cows and then sent the milk to a local creamery for processing butter and cheese. In short, they built up an industrial organization of agriculture, and, greatly helped by a corresponding increase in productivity, they succeeded in establishing a completely new production and marketing structure, mainly on a cooperative basis.

The growing numbers of farmhands and landless workers, who could not adapt themselves to the new agricultural situation, therefore had to go to the towns or perhaps to America in order to make a new start. From the late 1860's Danish land workers of both sexes emigrated in their thousands. The American pioneer farmers in turn profited greatly by this "flight to America", as the poor immigrants often had to work for several years as farmhands before they could hope to rent or perhaps buy a farm on the prairie. How much of their Danish agricultural training they were able to transplant is much debated. However, as I have tried to show earlier in this article, there is a marked tendency among younger American scholars to supplement the national, so to speak, approach with the ethnical one. 
I will end this note by calling for a closer cooperation between American and Danish scholars in the study of the agricultural development of the late 19th century. The use of a rather highflown heading to this article might be somewhat justified if we could supplement the said methodological re-orientation with an organizing one. The problems which the American and Danish farmers were facing werefundamentally of the same nature, even if the pioneers on the prairie worked with problems of land reclamation and the building-up of the farm, which were things of the past to their Danish colleagues. On the other hand, the American farmers were unquestionably more ready to employ modern equipment and technique. By studying these two processes, which are both akin and yet different, American and Danish scholars might profit greatly by cooperating in the framework of a joint project.

\section{N O T E S}

1 Whereby We Thrive: A History of American Farming, 1607-1972 (Ames, Ia.: The Iowa State University Press 1975).

2 "On a Certain Parelellism in Form Betwen Two Historical Processes of Productivity Growth" in Two Centuries of American Agriculture, ed. Vivian Wiser (Washington, 1976).

3 William N. Parker, ed., Structure of the Cotton Economy of the Antebellum South (Washington, 1970), Darwin P. Kelsye, ed., Farming in the New Nation: Interpreting American Agriculture, 1890-1940 (Washington, 1972), James W. Whitaker, ed., Farming in the Midwest, 1840-1900 (Washington, 1974), James H. Shideler, ed., Agriculture in the Development of the Far West (Washington, 1975), Thomas R. Wessel, ed., Agriculture in the Great Plains, 1876-1936 (Washington, 1977).

4 F. J. Turner, The Significance of the Frontier in American History (1894).

5 "The Historian as Mythmaker: Turner and the Closed Frontier", in The Frontier on American Development: Essays in Honor of Paul Wallace Gates., ed. David M. Ellis (Ithaca, N.Y. : Cornell University Press, 1969), p. 4.

6 Ellis, pp. 18-19.

7 Thomas C. Colbert, "James C. Malin", Great Plains Journal, 18 (1979), pp. $48-54$.

8 Ellis, p. 9.

9 The Sod Hose Frontier: A Social History of the Northern Plains from the Creation of Kansas and Nebraska to the Admission of the Dakotas (1937).

10 The Illinois Central Road and Its Colonization Work (Cambridge: Harvard University Press, 1934).

11 Winter Wheat in the Golden Belt of Kansas: A Study in Adaption to Subhumid Geographical Environent (Lawrence: University of Kansas Press, 1944).

12 Thomas H. Le Duc, "An Ecologic Interpretation of History: The Work of James C. Malin as Historian and as Critic of Historians", Nebraska History, XXXI (March 1950), pp. 226-33. 
13 Solon J. Buck, The Agrarian Crusade (1920), John D. Hicks, The Populist Revolt (1931).

14 Walter T. K. Nugent, The Tolerant Populists: Kansas Populism and Nativism (1963).

15 Norman Pollack, The Populist Response to Industrial America (1962), K. D. Bicha; "The Conservatie Populists: A Hypothesis", Agricultural History, 47 (1973), pp. 9-24.

16 American Farmer Movements (1957).

17 "A-Post-Mortem on the Labor-Safety-Valve Theory", Agricultural History, 19 (1945), pp. 31-00. See also Clarence H. Danhof, "Farm Making Costs and the Safety Valve", Journal of Political Economy, 49 (1941), pp. 317-59.

18 Her most important book is Patterns from the Sod: Land Use and Tenure in the Grand Prairie, 1850-1900, Collections of the Illinois State Historical Library Land Series, XXXV, vol 1 (1959).

19 Money at Interest: The Farm Mortgage on the Middle Border (Ithaca, N.Y.: Cornell University Press, 1955).

20 From Prairie to Corn Belt: Farming on the Illinois and Iowa Prairies in the Nineteenth Century (Chicago: University of Chicago Press, 1963).

21 Land Speculation and Frontier Tax Assessments", Agricultral Hitory, 44 (1970), pp. 253-66.

22 Acres for Cents: Delinquent Tax Auctions in Frontier Iowa (Westport, Conn.: Greenwood Press, 1976).

23 Donald L. Winthers, "Tenant Farming in Iowa, 1866-1900: A Study of the Terms of Rental Leases", in Farming in the Midwest, 1840-1900, ed. James W Whitaker (Washington, 1974) pp. 130-54.

24 Homer E. Socolofsky, Landlord William Scully (Lawrence: The Regents Press of Kansas, 1979).

25 Gould P. Colman, "Innovation and Diffusion in Agriculture". Agricultural History, 42 (1968), pp. 173-87.

26 Farm Size and Work Ethic: Measuring the Success of Immigrant Farmers on the American Grasslands, 1875-1925', Journal of Historical Geography, 4 (1978), pp. 57-76, "The Mobility of Immigrants and Americans: Comparison of Farmers on the Kansas Frontier", Agricultural History, 53 (1979), pp. 576-96.

27 "A Population Study of an Iowa County in 1850", Iowa Fournal of History, 57 (1959).

28 The Making of an American Corimunity : Democracy in an Frontier County (Stanford: Stanford University Press, 1959).

29 Bogue, From Prairie to Corn Belt.

30 "The Effect of Community on Migration: Three Minnesota Townships 1885-1905', Journal of Historical Geography, 5 (1979), pp. 403-22. 